\title{
Fin de siècle
}

\author{
Beverly Brahic
}

\begin{abstract}
Alors qu'une grève allait prendre fin, à Paris, une altercation avec d'autres conducteurs survient. L'invisibilité des femmes est manifeste, reflétée par les médias qui couvrent cette grève, seuls les métiers traditionnellement féminins étant représentés : infirmières, femmes de travailleurs des chemins de fer à la retraite qui font la cuisine pour les grévistes. Soupe de lentilles, pain et vin, une atmosphère extraordinaire de communion rapportent les médias. Ce sera un soulagement de retourner à la routine dont les objectifs auront été presque oubliés : le pouvoir, mais pour qui et pour faire quoi? En pensant à la femme qui a conduit le premier train, elle s'interroge:à moins que cela n'ait étéqu'une question de chevalerie?
\end{abstract}

'And now, what's going to happen to us. .?'

(Waiting for the Barbarians, C.P. Cavafy)

In the third week, when the strike was ending, Isabelle was the first driver back on the job: aged thirty, with a turtleneck under her uniform, also (reported the evening paper) a choker of cultured pearls. She stowed her purse in the cab, in it the letter management had sent all the strikers containing the usual guarantees about pensions and reprisals.

A dry run. Vincennes to Neuilly, getting a hand back in and the rust off the tracks. She was ready to pull out when her boss informed her she'd be taking passengers, although, frankly, he thought there wouldn't be many.

Nation station. A group of angry drivers accosts her. Tell her she's crazy to believe what that letter says: 
I bet they called you at home last night.

We've seen it all on TV-the parades, the strikers forking sausages that spit fat onto railway sleepers blazing in sawed-off oil drums-and envied their old time camaraderie. Their solidarity.

But I don't recall seeing women emerge from those meetings and get a rise from the jousting mikes, just the usual human interest stuff: nurses who bunked down at work; the retired railwayman's wife who pitched a tent and cooked meals for the strikers up north, where everyone chipped in to ladle out lentil soup, with wine and bread-great atmosphere, they said, like communion.

It was a relief to get back to routine.

We lost interest in hearing how others coped, leaving at $5 \mathrm{am}$, coming home late, the hitchikers, the bikers, the skaters, the conviviality, and so on.

Could be we hadn't got what the struggle was about. Power, of course, but for whom and to do what?

Still the news said a woman drove the first train and no one could stop her. So that's a change-

unless it was simply a question of chivalry. 